\title{
The Models of Village Fund's Management at Wukirsari, Imogiri, Bantul, Yogyakarta
}

\author{
Ahmad Lukman Nugraha \& Septrida Kurniawati \\ Universitas Darussalam Gontor \\ Jl. Sanan No.KM 6, Dusun I, Demangan, Siman, Kabupaten Ponorogo, Jawa Timur 63471 \\ Email: ahmad.lukman.n90@gmail.com
}

\begin{abstract}
The paper aims: first, to investigate the management of village fund in Wukirsari village and second, to analyze the influence of village fund towards the achievement of welfare of society in this village based on Mashlahah concept. The method used mixed method with Concurrent Triangulation model by combining equally between qualitative and quantitative method. The collecting data uses interview and questionnaire. the conclusion are; first, the management of village fund is established on annually program of development, while the implementation is managed by a teamwork of village development consists of government and society. All of development activities are completely controlled by the Head of Village and the Monitoring team. Second, the analysis shown that village fund has a positive influence toward welfare. The result of $t$ test that analyzed by simple regression analysis concluded the value of village fund coefficient is 10,739 and $t$ table is 1,661 . It shows that $t_{\text {arithmetic }}>t_{\text {table }}(10,739>1,661)$. Coefficient determination value shows the result of adjusted $R$ Square is 0.538 means that village fund variable $(X)$ has $53,8 \%$ significance influence towards Mashlahah of society.
\end{abstract}

Keywords: Village fund, Welfare of society, Mashlahah concept.

\begin{abstract}
Abstrak
Tujuan penelitian ini adalah Pertama, untuk mengkaji sistem pengelolaan dana desa yang dilaksanakan di desa Wukirsari. Kedua, untuk mengetahui apakah dana desa berpengaruh pada pencapaian kesejahteraan yang berdasarkan pada Mashlahah. Metode penelitian ini menggunakan metode kombinasi dengan model analisis Concurrent Triangulation Model yaitu dengan menggabungkan antara metode penelitian kualitatif dengan kuantitatif secara seimbang. Pengumpulan data menggunakan interview dan kuesioner. kesimpulan penelitian ini adalah; pertama, bahwa pengelolaan dana desa diawali dengan musyawarah program pembangunan dengan masyarakat tingkat dusun yang nantinya akan dibentuk ke dalam RJPMDes, adapun pelaksanaan pembangunan dilaksanakan oleh Ka. Sie. Kesejahteraan yang didampingi oleh Tim Pelaksana Kegiatan (TPK) dan masyarakat. Kegiatan pembangunan desa yang dilaksanakan di Desa ini secara penuh diawasi oleh Kepala Desa beserta beberapa Tim Monitoring dari Kabupaten dan BPD. Kedua, dana desa sudah mencapai kesejahteraan masyarakat yang mencakup lima aspek Mashlahah. Berdasarkan hasil penghitungan analisis regresi sederhana menghasilkan nilai koefisien dana desa yaitu 10,739 dengan $t$ tabel 1,661 yang berarti $t_{\text {hitung }}>t_{\text {tabel }}(10,739>1,661)$. coefficient determination juga menunjukkan hasil adjusted $R$ Square 0.538 yang berarti dana desa memiliki pengaruh yang signifikan terhadap kesejahteraan masyarakat dalam konsep mashlahah sebesar $53,8 \%$. Sedangkan sisanya dijelaskan oleh variabel lain yang tidak dibahas dalam penelitian ini.
\end{abstract}

Kata kunci: Dana desa, Kesejahteraan masyarakat, Konsep Mashlahah.

\section{INTRODUCTION}

Poverty is a basic problem of macroeconomy, particularly in the developing country. It is noted that the number of poor population in Indonesia on March 2016 reached 17, 67 million for rural and 10, 34 million for urban areas (Badan Pusat Statistik, 2016). Because of that problem, state government always do 
some efforts to reduce the poverty by increasing the economic growth through supplying some funds for funding the economic development of village in order to achieve the welfare of society.

Hornby (2015: 504) defined welfare means as the health, happiness and pleasure from some population or individu. In the framework of Islamic Economics, the real welfare of society would be achieved if the basic mashlahah of human life which consists of two aspects of spiritual and material is fulfilled. Those five aspects are preservation of religion, physical-self, intellect, family and wealth (P3EI, 2014). Therefore Mashlahah becomes tool that needed to measure the welfare of society and for a good viability, while it is become the main goals in economic development of the nation. (Muhibuddin, 2016).

Village fund are funds sourced from 10\% State General Revenue and Expenditure Budget (APBN) allocated to the villages used for financing the governmental activities, village development, civil society development and community empowerment (BPKP, 2015). This program is established since 2015 which allocated for economic development through funding the development of infrastructure and village facilities physically. (Peraturan Menteri Desa, 2016).

Good management of village fund could build the economic growth rapidly and achieve the welfare of society. The systematic management is not only done by the village government, but also it needs the accompaniment from state government/ regency and the participation from society. In this case, the village government needs to form a teamwork to manage the implementation of this program.

Wukirsari is a village situated in Bantul regency, Yogyakarta which becomes as one of the village that received the village fund donation since it began at 2015, and becomes the best village in the absorption of Village Funds" (Republika, 2016) The economic growth in this village increases rapidly because of its potency that owned and the good management of village fund implementation.

This research purposed; firstly to know the management of village fund donation which is done in Wukirsari village. Secondly to analyze the influence of its implementation towards the achievement of welfare of society according to mashlahah concept.

\section{RESEARCH METHODS}

The researcher uses mixed method with Concurrent Triangulation Model approach. Sugiyono (2016) said It was combining the qualitative research method and quantitative research method with mixing both methods in a balanced (50\% qualitative and $50 \%$ quantitative). Qualitative approach in this research method is used to know about the management of village funds in Wukirsari village. While the quantitative method is used to examine the influence of village fund to the welfare of society, while village fund stated as the independent variable $(\mathrm{X})$ and Welfare of society stated as dependent variable $(\mathrm{Y})$ of the research. The object in this research is Wukirsari village. While the informants of interview about the management of village fund are the financy of village and the chief of division of welfare in Wukirsari village, and the respondents are come from the society of this village which the sample is chosen by Cluster sampling technique.

\section{RESULTS AND ANALISIS}

\section{The Management of Village Fund in Wukrisari Village}

Based on the focus of this research, here are the results of research which done through direct interview with some determined informants/sources, those are the treasurer of Wukirsari village and ka.sie. kesejahteraan masyarakat in Wukirsari village government.

\section{Planning}

The basic step of management is planning. Stoner and Wankel (1993) defined that strategic planning is the process of arranging the purpose of organization, determination of policy and program that is needed to achieve some goals, and the decision of methods to certify that the policy and strategic program implementable appropriated with the capability and developed condition. (Abu Sinn, 2012: 79).

Village development program is established in RPJMDes which arranged 
annually. This program is arranged by 3 administration divisions of village government, those are the division of welfare ( $K a$. Sie. Kesejahteraan), the division of village adminitrsation (Ka.Sie. Pemerintahan), and the division of community service (Ka. Sie. Pelayanan). While village fund program is arranged in RPJMDesa which made by the division of welfare (Ka. Sie. Kesejahteraan) of Village Government. This section is arranging the development program which would be funded by village fund before it is being discussed with some of community and TPK(Tim Pelaksana Kegiatan) in further deliberation. (Transcript of Interview , 2017)

Soon after RJPMDesa have been settled and accepted with the head of village, the financy submit them to the local government as the submission requirements of village fund donation stage I on the first semester. While the submission requirements of village fund donation stage II is the realization report of village development process which funded from village fund donation on early semester. (Transcript of Interview , 2017).

When the local government accepts the submission requirement from village government, the financial department of local government will transfer $60 \%$ of village fund donation to the village account for funding the development program of village. The development program which sourced by village fund is more prioritized for physically development of infrastructure for village society in every hamlets smoothly. (Transcript of Interview , 2017).

\section{Organizing}

The manager of village fund donation is done by the team of village fund, which consists of: The responsible of Operational Activities (Penanggungiawab Operasional Kegiatan/PJOK) is the Chief of Village, The responsible of Village Development program or as the responsible of village fund Program Adminisration (Penangungjawab Administrasi Kegiatan/PJAK) is the division of Welfare ( $K a$. Sie. Kesejahteraan), Financial department as the chief of financial administration, The team of management activities (Tim Pelaksana Kegiatan/ TPK) as the organizer of actualization program of development in the village and hamlets, Development Committee as the counterpart staff of actualization program (Transcript of Interview, 2017).

The personnel of village fund organizer above who manage the realization of village development program which sourced from village fund.

\section{The Structure of Village Fund Manager}

\section{The Structure of Village Fund Manager}

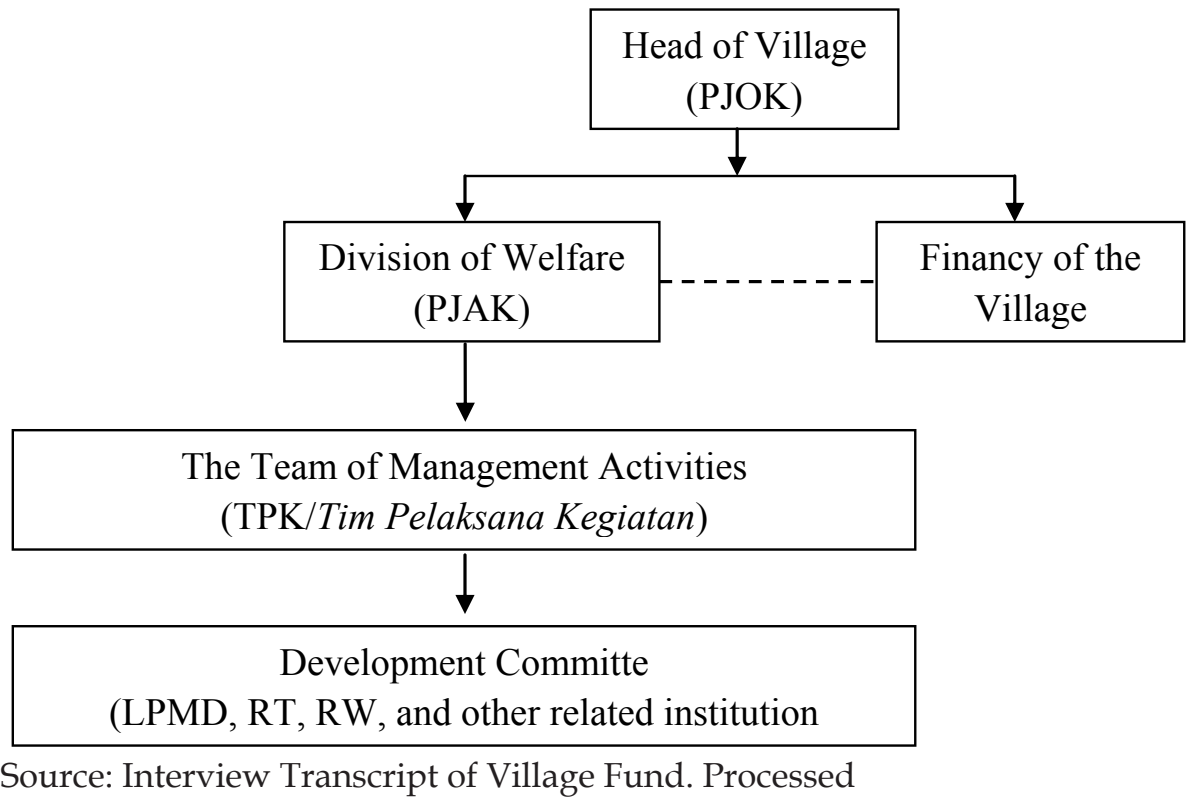


The figure above described about the managers of village fund. Each division has their own duties in managing village fund (Transcript of Interview, 2017). These are the duties of each division of village fund management:

The head of Village: as the guidance of all village development activities, and accepts the realization report of village development program, and as activities supervisor

Division of Welfare (Ka. Sie. Kesejahteraan): as the general manager of village fund program, establishing the budget of village fund, fixing the development program, cashing down the Fund, expending the tools that needed in the program to related institution, making a report of program realization, and reporting the financial audit report to the financy of village

Financy of village: as the general manager of financial relation, accepting and checking the financial audit of realization program, submitting the submission requirements to local government, and submitting the financial audit of realization to local government

The Team of Management Activities (TPK/Tim Pelaksana Kegiatan): the manager of village development implementation in village and hamlets, submitting the budget tools, accepting the development tools, making a report of realization program and financial audit, and doing an action of village development program

Development Committe: helping the actualization and implementation of village development in each hamlets, as the supervisor of village development implementation

This team of village fund management is created to organize the village fund program in order to achieve the goal of development properly. Based on the government regulation of village fund priority usage, the development is only concern at infrastructure development and society empowerment. But by purposely in Wukirsari village, the priority usage of village fund is only concern in infrastructure development. The government manages in such a manner because for the development is spent much funding. Therefore village fund is almost allocated entirely for development program. While village is also had some other kinds of donation for funding the society empowerment such as the allocation of village fund (ADD) which is the budget of ADD is cashed down monthly. (Transcript of Interview, 2017)

\section{Actuating}

The management of village fund is done totally by the team of village fund consist of the division of welfare in the village government (Ka. Sie. Kesejahteraan), accompanied by the The Team of Management Activities (TPK/Tim Pelaksana Kegiatan) and development committee in its actualization and implementation with the defined mechanism. (Transcript of Interview , 2017).

While the mechanism of village fund management is properly done through: Cashing down the donation fund with PJAK of village fund, Expending of tools for village development to the related institutions, Allocating the tools for village development to the teamwork, Doing the development project in each hamlets with the society and related institutions led by TPK, Reporting the realization of village fund development by TPK and the teamworks (Transcript of Interview, 2017)

\section{Controlling}

Management of village fund program is done under the supervising of some governmental parties. Based on the government regulation of village development program, the main supervisor of village fund management is the Head of Village which accompanied by the monitoring team that comes from local government to supervise the process of village development in each village. The other supervisor also comes from Village Centralization Board (Badan Pemusatan Desa/ $\mathrm{BPD})$. The Head of Village, BPD and monitoring team commisioned as the supervisor of the development process (Transcript of Interview, 2017). Controlling of village fund is done since the beginning of establishing village development program to making the report of realization and financial audit.

The Influence of Village Fund towards the Achievement of Welfare of Society

After doing the validity and reliability test, the researcher results 35 valid and reliable 
research instruments to analyze the influence of village fund toward welfare of society according to mashlahah concept. Here, the instrument are consists of two variables in both village fund as independent $(X)$ and welfare of society as dependent variable $(\mathrm{Y})$.

The calculation of the analysis is using SPSS for window 16.0, and shows the results:

\section{Simple Regression Analysis}

Regression analysis is used to examine the influence between independent variable and dependent variable. (Sujarweni, 2015) The result of Simple Regression analysis is shown in the table below:
Based on the table above, it results the equation of simple regression analysis as follows:

$$
\begin{gathered}
Y=a+b x \\
Y=15.108+1946 x
\end{gathered}
$$

Explanation:

$\mathrm{Y}=$ welfare of society based on Mashlahah

a $=15.108$

$\mathrm{b}=1946$

From the simple regression analysis above described the results as follows:

- Constanta is 15.108 with positive value; means that if village fund $(X)$ is 0 , then the value of welfare of society based on Mashlahah $\left(\mathrm{Y}^{\prime}\right)$ is 15.108

Table 1. Research Framework; The Latticework/ Matric of Research Instrument Development And

\begin{tabular}{|c|c|c|}
\hline VARIABLE & DEFINITION OF VARIABLE & INDICATOR \\
\hline $\begin{array}{l}\text { Village fund } \\
\text { Implementation }(X)\end{array}$ & $\begin{array}{l}\text { The distribution of -Village fund in order to } \\
\text { development - process }\end{array}$ & $\begin{array}{l}\text { Village Development } \\
\text { Society Empowerment }\end{array}$ \\
\hline Welfare of Society $(\mathrm{Y})$ & $\begin{array}{l}\text { To promote the welfare of the people based on } \\
\text { Mashlahah concept, -which lies in preventing } \\
\text { their religion (diin), their physical-self (nafs), } \\
\text { their intellect ('aql), their -family (nasl), and } \\
\text { their wealth (maal). }\end{array}$ & 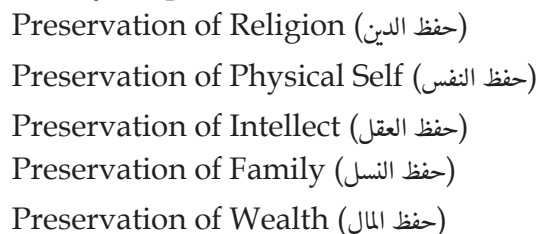 \\
\hline
\end{tabular}
Variable Definition

Source. The summary of literature review and theoretical framework

\begin{tabular}{|c|c|c|c|}
\hline \multicolumn{4}{|c|}{ Variables Entered/Removed ${ }^{b}$} \\
\hline & Variables & Variables & \\
\hline Model & Entered & Removed & Method \\
\hline 1 & Dana Desa ${ }^{a}$ & & Enter \\
\hline
\end{tabular}

Table 2. Simple Regression Analysis Result

ANOVAb

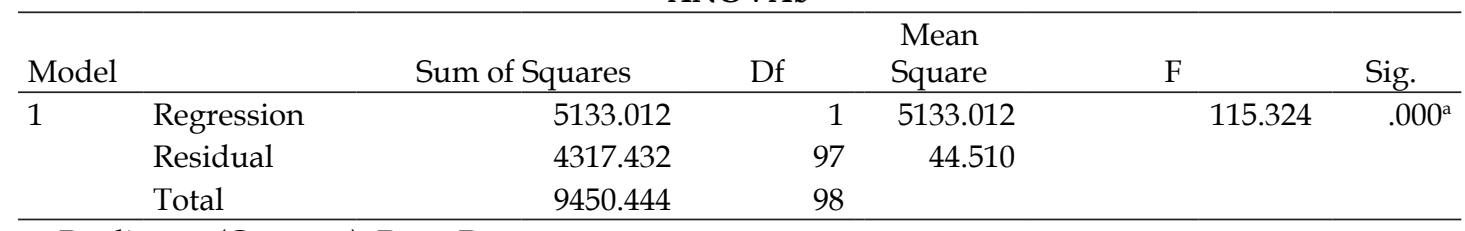

a. Predictors: (Constant), Dana Desa

\begin{tabular}{|c|c|c|c|c|c|c|c|}
\hline \multicolumn{8}{|c|}{ Coefficients } \\
\hline \multirow[t]{2}{*}{ Model } & & Unstanc & nts & $\begin{array}{c}\text { Standardized } \\
\text { Coefficients }\end{array}$ & & \multirow[t]{2}{*}{$\mathrm{T}$} & \multirow[t]{2}{*}{ Sig. } \\
\hline & B & & & Beta & & & \\
\hline \multirow[t]{2}{*}{1} & (Constant) & 15.108 & 6.491 & & & 2.327 & .022 \\
\hline & Dana Desa & 1.946 & .181 & & .737 & 10.739 & .000 \\
\hline
\end{tabular}

b. Dependent Variable: Mashlahah

a. Dependent Variable: Mashlahah

Source. Output result of SPSS for window 16.0 
The value of coefficient regression of village fund variable $(X)$ is 1946; means that if village fund increases 1 level, then the volume of welfare of society based on Mashlahah $\left(\mathrm{Y}^{\prime}\right)$ would increase 1946. Thus, Mashlahah of society will be increased if village fund is increased or managed properly.

Coefficient valuable positive means a relationship that occurred between Dana Desa and welfare of society based on Mashlahah is a positive relationship.

\section{T Test}

This test is used to know the significant influence of independent variable $(X)$ towards dependent variable $(Y)$. Significant means that the influence that occurred to the sample is usable for total population (generalizability). Based on the output above described the result of $t$ value is 10,739 with the significance level $5 \%$.

- The Research hypothesis:

Ho : There is no influence between village fund and welfare of society based on Mashlahah

Ha : There is an influence between village fund and welfare of society based on Mashlahah

- Manners:

If Sig > 0,05 then Ho accepted

If Sig $<0,05$ then Ho rejected

And or,

If $-\mathrm{t}$ table $<\mathrm{t}$ arithmetic $<\mathrm{t}$ table then Ho accepted

If $\mathrm{t}$ arithmetic $<-\mathrm{t}$ table and $\mathrm{t}$ arithmetic $>\mathrm{t}$ table then Ho rejected

- The results of interpretation:

- From the research above explained that sig is 0,000 which means $<0,05$; then Ho is rejected

- Based on $t$ table with Degree of Freedom $(\mathrm{df})=97$ by the significance level $=0,5$ or $5 \%$ resulted that $t$ table is 1,661 and $\mathrm{t}$ arithmethic is 10,739 , then shown that $\mathrm{t}$ arithmetic $>\mathrm{t}$ table $(10,739>1,661)$; means that Ho is rejected.

From both interpretations, concluded that Ho is rejected, which means village fund is has a significance influence toward Mashlahah. Coefficient Determination Analysis
Table 3. Result of Coefficient Determination $\left(\mathbf{R}^{2}\right)$

\begin{tabular}{lcccc}
\multicolumn{5}{c}{ Model Summary } \\
\hline Model & $\mathrm{R}$ & $\mathrm{R}$ & $\begin{array}{c}\text { Adjusted R } \\
\text { Square }\end{array}$ & $\begin{array}{c}\text { Std. Error of the } \\
\text { Square }\end{array}$ \\
\hline 1 & $.737^{\mathrm{a}}$ & .543 & .538 & 6.672 \\
\hline a. Predictors: (Constant), Dana Desa \\
Source. Output result of SPSS for windows 16.0
\end{tabular}

Coefficient determination $\left(R^{2}\right)$ is the rate of variation that can be described by village fund variable $(\mathrm{X})$ towards Mashlahah variable $(\mathrm{Y})$. If the value of $R^{2}$ is progressively close to 1 value, it means that village fund variable $(X)$ towards Mashlahah is gaining greater and vice versa.

Based on the analysis above resulted that Coefficient Determination $\left(\mathrm{R}^{2}\right)$ is 0.538 which means that the variation of village fund towards Welfare of Society according to Mashlahah concept is about $53,8 \%$.

\section{CONCLUSION}

The researchers concludes the management of village fund in Wukirsari Village and its influence toward welfare of society according to Mashlahah concept:

Village fund implementation program in this village run through systematical management based on good management theory includes planning, organizing, actuating, and controlling.

Planning steps are done through arranging the annually program of village development and establishing the priority of development according to the necessities of society. Management village fund is under the responsibility of head of village and for the organizer of its implementation is led by $k a$. sie. Kesejahteraan masyarakat accompanied by Tim Pelaksana Kegiatan (TPK) and the committee of development from the society. This fund is used to actualize public facilities physically based on its priority which is explained on the government regulation. Its facilities are consist of health facility, worship facility, educational facilities, economy and business facility, and so on. To achieve the goal of development, village fund management also controlled and supervised by the governmental parties in order to keep monitoring its implementation in the village. 
Based on the result of $t$ test that analyzed by simple regression analysis concluded that the value of village fund coefficient is 10,739 and $t$ table is 1,661 . It shows that $t_{\text {arithmetic }}>t_{\text {table }}$ $(10,739>1,661)$ which means Hi that expresses village fund has an influence toward welfare of society according to mashlahah is accepted. Based on coefficient determination value also shows the result of adjusted R Square is 0.538 means that this model explains the influence of village fund toward welfare of society according to mashlahah around $53,8 \%$ while $46,2 \%$ are explained from another variable. Where the increase of village fund would increase the achievement of Mashlahah. It means that village fund has much significance role to increase the welfare of society through the good management and proper goal achievement. If the village fund management is done properly it would soon increase the rural economic growth which soon after would push to the increase of economic growth of state.

\section{REFERENCES}

AS Hornby, 2015, Oxford Learner's Pocket Dictionary, Fourth Edition, Oxford: Oxford University Press

Badan Pusat Statistik, Statistik Resmi tentang Profil Kemiskinan di Indonesia pada bulan Maret 2016, published on July 18, 2016

Muhibuddin, "Sejahtera dan Relevansinya dengan Mashlahah dalam Tinjauan Ekonomi Syari'ah", Jurnal Al-Buhuts IAIN Gorontalo, (Volume 10, Number 1, June 2014)

P3EI, 2014, Ekonomi Islam, $6^{\text {th }}$ Edition, Jakarta: PT. Raja Grafindo Persada

Peraturan Menteri Desa, Pembangunan Daerah Tertinggal, dan Transmigrasi Republik Indonesia Nomor 21 Tahun 2015 tentang Penetapan Prioritas Penggunaan Dana Desa 2016
Peraturan Menteri Keuangan Republik Indonesia Nomor 49/PMK. 07/2016, Tentang Tata Cara Pengalokasian, Penyaluran, Penggunaan, Pemantauan dan Evaluasi Dana Desa

Peraturan Pemerintah Republik Indonesia Nomor 60 Tahun 2014, tentang Dana Desa Yang Bersumber Dari Anggaran Pendapatan dan Belanja Negara

Republika Daily Newspaper, Wednesday, 15 of March 2017/16 Jumada Tsaniah 1438H

Republika Daily Newspaper, Friday, 3 of March 2017/3 Jumada Tsaniah 1438H

Rosalinda, Okta. 2014, "Pengelolaan Alokasi Dana Desa (ADD) dalam Menunjang Pembangunan Pedesaan", Scientific Journal of Economic and Bussiness Faculty of Brawijaya University, Malang, June 25.

Saputra, Elvan, et. al, "Maslahah as an Islamic Source and its Application in Financial Transactions", Journal of Research in Humanities and Social Science, (Volume 2, Number 5, 2014)

Sinn, Ahmad Ibrahim Abu, 2012, Manajemen Syariah Sebuah Kajian Historis dam Kontemporer, $3^{\text {rd }}$ Edition, Jakarta: PT. Raja Grafindo Persada

Sugiyono, 2016, Metode Penelitian Kombinasi (Mixed Method), $8^{\text {th }}$ edition, Bandung: Alfabeta

Sukanto, Azwardi, 2014, "Efektifitas Alokasi Dana Desa (ADD) Dan Kemiskinan Di Provinsi Sumatera Selatan", Economic Development Journal. Volume 12, Number 1, June 2014, p. 29-41.

Transcript of Interview with Kepala desa in Balai desa, 2017.

Transcript of Interview with Skretaris desa in Balai desa, 2017.

Transcript of Interview with Bendahara desa in Balai desa, 2017. 